Morandi, Alessandro

1982 Epigrafia italica. Rome: Bretschneider.

Pisani, Vittore

1953 Sulla lingua dei siculi. Bollettino del Centro di Studi Filologici e Linguistici Siciliani 1: $5-18$.

Prosdocimi, Aldo Luigi

1978 Una nuova iscrizione anellenica da Montagna di Marzo. Kōkalos 24: 16-40.

De Simone, Carlo

1999 L'epigrafia sicana e sicula. Annali della Scuola Normale Superiore di Pisa. Serie IV, Quaderni 2: 499-507.

De Simone, Carlo

2006 Ancora su Siculo e Sicano. In: Chiara Michelini (ed.), Guerra e pace in Sicilia e nel Mediterraneo antico (VIII-III sec. a.C.). Arte, prassi e teoria della pace e della guerra. Vol. II. Pisa: Scuola Normale Superiore, 689-692.

Watkins, Calvert

1995 Greece in Italy outside Rome. Harvard Studies in Classical Philology 97: 35-50.

Whatmough, Joshua

1933 The Prae-Italic Dialects of Italy. Vol. II. Part III. Cambridge, MA: Harvard University Press.

Zamboni, Alberto

1978 Il siculo. In: Aldo Luigi Prosdocimi (ed.), Lingue e dialetti dell' Italia antica. (Popoli e civiltà dell'Italia antica 6). Rome: Biblioteca di Storia Patria. 949-1012.

Markus Hartmann, Erfurt (Germany)

\title{
106. Lusitanian
}

1. Documentation

2. Phonology

3. Morphology

4. Syntax
5. Lexicon

6. The position of Lusitanian within Indo-European

\section{Documentation}

Lusitanian (Lus.), also Lusitano-Galician, is the modern exonym for a fragmentarily attested IE language in the West of the Iberian Peninsula, extending from the Atlantic Coast to the western borders of Castilia and from the Douro in the north to the Guadiana and the lower Tajo in the south. The name is derived from the ancient Lusitani in whose area the inscriptions were found. For the historical background see Pérez Vilatela (2000).

Five short inscriptions (Arroyo de la Luz I and II - a single text, now lost; the fragmentary Arroyo de la Luz III; Lamas de Moledo; Cabeço das Frágoas; Ribeira da Venda near Arronches, Portalegre; altogether around 100 words) have been found so far (Untermann 1997: 747-758; Villar and Pedrero 2001; Carneiro et al. 2008). To these 
can be added a number of "quasi-Lusitanian" texts (short Latin inscriptions containing isolated Lus. forms; Witczak 2005: 183-198), onomastic material (Vallejo Ruiz 2005) and divine names and epithets on Roman inscriptions (Prósper 2002: 89-354), placenames, words transmitted in external sources, and lexical material in Ibero-Romance languages that is suspected of having been borrowed from Lus. (Witczak 2005: 295390).

All documents are written in the Roman script. The possible time-frame for the inscriptions extends from the $1^{\text {st }} \mathrm{c}$. BCE to the $2^{\text {nd }} \mathrm{c}$. CE, but due to the lack of archaeological contexts the chronology remains conjectural; dating the texts on linguistic grounds is circular.

The limited corpus creates several methodological problems: there probably never existed a written literary standard for Lus.; the inscriptions reflect independent attempts at putting the vernacular into writing on the basis of Latin school education. So far no consensus has been reached on the interpretation of the texts, and the situation is aggravated by their insecure readings. Due to Lus.'s lamentable state of preservation, anything said about its synchronic and historical grammar is necessarily conjectural only.

\section{Phonology}

\subsection{Vowels}

The vocalism exhibits relatively conservative traits. Partly divergent treatments of long and short vowels suggest a length opposition (not indicated in writing) for Lus., or for an earlier stage of the language. The observable vowel changes are largely isolated phenomena and do not transform the inherited system as a whole:

- $e$ is raised to mid-high $l<\mathrm{i}$, e $>$ before tautosyllabic nasals, perhaps sporadically in other contexts as well.

- $i$ in hiatus (or $i$ ) before back vowels is frequently written $e$.

- $o$ may be syncopated in final syllables between $i$ and a consonant.

$-e(=\bar{e})<* e i$ at least in final syllables.

Both $i$ - and $u$-diphthongs are frequent. The $i$-diphthongs display great variation in spelling (e.g. ae, ai, aei). Beside one good example for ou $<* e u$, there are several words with written $e u$.

Occasional further vowel variation is suspect of being morphologically conditioned (cf. 3.1).

\subsection{Resonants}

$r, l, m, n$, and $i$ remain largely unchanged. The inherited distinction between $m$ and $n$ is retained in auslaut. $u$ is lost between $o$ and $i / e$; in a few cases the rare grapheme $f$ stands in initial position of words that are compared to etyma with $u$ outside Lus. 


\subsection{Consonants}

There is an opposition between plain and geminated stops and resonants. An original opposition between voiced and voiceless stops has been partly transformed, because word-internally the obstruents have undergone a sound-shift. Variant spellings with letters for voiceless and voiced stops side by side indicate that inherited voiceless stops had become phonetically voiced ("lenited") between vowels and after resonants, but that this distributional allophony had not yet attained phonemic status. There is the potential for inverse spellings in such a situation. It is likely that the development was caused by a pull chain from a previous, analogous "lenition" (probably fricativization) of voiced stops, which is not indicated in spelling.

It is unclear whether the PIE voiced and voiced aspirated obstruent series had merged or had stayed separate. The examples adduced by Witczak (2005: 255-257, 267-274) for a separate treatment of the two series (i.e. Lus. $f, b, p<* b^{h}$, but $b<* b$; Lus. $\emptyset<$ $* h<* g^{h}$ and ${ }^{*} g^{h}$, but $g / \emptyset<* g$ and $* \hat{g}$; Lus. $r<* d$, but $d<* d^{h}$ ) rest on doubtful etymologies.

Lus. has undergone the same kentum-development as all Western IE languages (e.g. porcom $<*$ porkom). The evidence for the fate of the labiovelars is ambiguous. It has been suggested that unlike in other kentum-languages PIE $* k^{u}$ and $* k u / \hat{k} u$ did not merge, but rather that $* k^{u}$ became Lus. $p$ and $* k u / \hat{k} u$ remained as Lus. <qu> (Prósper 2002: 396-397; Witczak 2005: 274-276).

$s$ generally remains in Lus. but is occasionally lost in final position (Stifter 20102011: 189-190).

\subsection{Accent}

Nothing positive can be said about the accent in Lus. But it is noteworthy that the vowels seem to have undergone more reductions in final syllables than in other positions, which indicates that the accent was not word-final.

\section{Morphology}

\subsection{Nouns}

Inherited IE inflectional categories are retained. All three genders seem to be attested. Only singulars and plurals are found. Attested cases are: nominative, accusative, dative, genitive, and possibly locative; the instrumental and ablative are uncertain. Of the inflectional classes, thematic (o-, io-stems) and athematic nouns ( $\bar{a}-, i \bar{a}_{-}, u_{-}$, consonant stems) are found; other classes ( $\bar{l}$-stems) are uncertain.

The endings are generally the expected ones. Noteworthy are: the thematic gen. sg. in $-o$, unless the forms are instrumentals; the thematic dat. sg., which vacillates between $-o i,-u i,-u,-o$; one inscription possibly has $\bar{a}$-stem dat. sg. $-a$ instead of $-a i$ elsewhere. If isaiccid and puppid are ablatives, the ending $-d$ has spread outside thematic nouns (but cf. 3.4). 


\subsection{Adjectives}

The evidence consists mainly of theonymic epithets. Adjectives inflect like nouns. In several instances, $O$-stem adjectives agree with $\bar{a}$-stem nouns. A superlative in -tamo- $<$ *-tmHo- is found.

\subsection{Numerals}

If autochthonous, the personal name Petranio- could be derived from '4', those in Pilent- from ' 5 '.

\subsection{Pronouns}

Several candidates for demonstratives have been cited (e.g. tadom, etom), but none is undisputed. Isaiccid and puppid (if $<*^{*} k^{u} o d k^{u} i d$ ) could be correlatives, unless they are nouns in the ablative. Iom is either a relative pronoun (perhaps correlative with demonstrative etom) or has some other subordinating function.

\subsection{Verbs}

By their endings, rueti and doenti are securely identifiable as $3 \mathrm{sg}$. and $3 \mathrm{pl}$. verbal forms, probably present indicative, although the root $\left(* d^{h} e h_{1}\right.$ or $\left.* d o h_{3}\right)$ and the stem formation of the latter is unclear. Verbal forms have also been suspected in praisom (1sg.?), praesondo (middle $3 \mathrm{pl}$. ?), singeieto (middle $3 \mathrm{sg}$.), and loiminna/loemina (middle participle?) but none of this can be proven.

\section{Syntax}

\subsection{Word classes}

In addition to the word classes discussed in 3, one function word has been securely identified: conjunctive indi.

\subsection{Word order}

The small corpus of Lus. yields only weak evidence for SVO. Other surface configurations are probably marked word orders in dedicatory contexts.

Adjectives follow their head noun. There are two possible cases of postpositions $($ Carlae en, praeson $=d o)$, but both can also be analyzed in other ways. 


\subsection{Sentence syntax}

One inscription contains a sequence of nine elements coordinated by the conjunction indi. One example of a subordinating pronoun, iom, gives evidence of a hypotactic structure, but lacks any context.

\section{Lexicon}

\subsection{Vocabulary}

Despite the limited corpus, the inscriptions are linked by several recurring words, a fact that helped establish Lusitanian as a linguistic entity. The number of semantically clear words is extremely small. Three words for sacrificial animals are securely identified (porcom, taurom, oilam). One inscription may contain a series of terms for social or family relations.

\subsection{Word formation}

Like in neighbouring Celtiberian, adjectival formations in -k- (-iko-, -aiko-, -tiko-) enjoy great productivity, e.g. teucaecom $\leftarrow$ teucom, lamaticom 'belonging to L.' $\leftarrow$ placename *Lama. Derivatives in -io/a - are also frequent (e.g. usseam <*ups-iii $\bar{a}$ - or *uts-ii $\bar{a}-$ ?).

There are compounds that consist of two nominal elements; others are made up of preverb + nominal element, but the exact formal and semantic types cannot be determined.

\section{The position of Lusitanian within Indo-European}

The IE character of Lus. is immediately apparent from the inflectional endings. It clearly belongs to the Western IE linguistic area and represents a rather typical "old-IE" language, but its genetic relationship to other IE languages remains disputed. Divine names are shared with the Gallaeci, north of the Lusitani.

A special relationship to Celtic has been suggested, but cannot be substantiated: similarities with Celtiberian in derivational morphology could reflect mutual influence (the potentially shared thematic gen. sg. in - $o$ is remarkable, unless the Lus. forms are instrumentals); lexical correspondences with Celtic (Lus. Crougeai $\sim$ OIr. crúach 'hill') rest on etymological speculation. More recently, similarities of Lus. with Italic have been stressed.

Although the few sources exhibit some variation in phonology and morphology, the evidence is too meager for secure inferences about diachronic or dialectal divergences. 


\section{References:}

Carneiro, André, José d'Encarnação, Jorge de Oliveira, and Cláudia Teixeira

2008 Uma inscrição votiva em língua lusitana [A votive inscription in the Lusitanian language]. Palaeohispanica 8: 167-178.

Pérez Vilatela, Luciano

2000 Lusitania. Historia y etnología. Madrid: Real Academia de la Historia.

Prósper, Blanca Maria

2002 Lenguas y religiones prerromanas del occidente de la Península Ibérica, Salamanca: Ediciones Universidad de Salamanca.

Stifter, David

2010-11 Schwund von auslautendem s als westeuropäische areale Erscheinung. Die Sprache 49/2: 187-193

Untermann, Jürgen and Dagmar Wodtko

1997 Monumenta Linguarum Hispanicarum. Band IV. Die tartessischen, keltiberischen und lusitanischen Inschriften. Wiesbaden: Reichert.

Vallejo Ruiz, José María

2005 Antroponimia indigena de la Lusitania romana. Vitoria-Gasteiz: Servicio Editorial Universidad del Pais Vasco.

Villar, Francisco and Rosa Pedrero

2001 Arroyo de la Luz III. Palaeohispanica 1: 235-274.

Witczak, Krzysztof Tomasz

2005 Język i religia Luzytanów. Studium historyczno-porównawcze [Lusitanian language and religion. A historical-comparative study]. Lodz: Wydawnictwo Uniwersytetu Łódzkiego.

David Stifter, Maynooth (Ireland)

\section{Macedonian}

1. Origin of the Macedonians and their language

2. Documentation
3. Linguistic features of Macedonian

4. Probable member of the Greek family

5. References

\section{Origin of the Macedonians and their language}

The Macedonians correspond to a group of tribes who, according to legend, were united by the Temenides in the $7^{\text {th }}$ century BCE, and who started to occupy valleys and plains progressively after having descended from the Pindos mountains. For a long time, their core area was the Haliacmon basin, where their first capital Aigeai was located. During the reign of Alexander I (ca. 498-454 BCE), they reached the Strymon river; in the time of Philip II they could be found near the Nestos river. Their northern border never spread much further than the current border of Greece (Brixhe and Panayotou 1997: 207-208). An originally heterogeneous country, Macedonia partly remained this way owing to 